\title{
NIEPEWNA NORMALIZACJA STOSUNKÓW POLITYCZNO-GOSPODARCZYCH IRANU Z ZACHODEM
}

Po prawie trzydziestopięcioletnim okresie prowadzenia przez władze Iranu antyimperialistycznej polityki wobec USA i pozostałych państw zachodnich w połowie $2013 \mathrm{r}$. nastapiła zmiana tej polityki. W czerwcu tego roku prezydent Iranu, szejk Hasan Rouhani, przy poparciu najwyższego przywódcy Ali Chameneia, za jeden z głównych celów swojej prezydentury wyznaczył normalizację stosunków politycznych i gospodarczych z państwami zachodnimi. Jednak faktyczną władzę w Iranie sprawuje nie prezydent, lecz Najwyższy Przywódca Ali Chamenei. Bez jego zgody niemożliwe byłoby podjęcie, jesienią 2013 r., negocjacji ze Stanami Zjednoczonymi i innymi państwami zachodnimi, których celem jest pełna normalizacja stosunków politycznych i gospodarczych z Zachodem oraz uzyskanie akceptacji Iranu i jego systemu politycznego przez społeczność międzynarodową.

Strona zachodnia uzależnia jednak odbudowę ,przyjaznych”, a przynajmniej „poprawnych" stosunków z Iranem od rezygnacji przez to państwo z budowy broni atomowej. Natomiast władze Iranu chciałyby prowadzić w pełni samodzielną politykę, także w kwestii realizacji swojego programu nuklearnego. Domagają się zmniejszenia wszystkich sankcji gospodarczych oraz rozwiązania wszystkich spornych problemów we wzajemnych stosunkach polityczno-gospodarczych z USA i pozostałymi państwami zachodnimi, a także uznania przez te państwa swojego suwerennego prawa do rozwoju potencjału nuklearnego dla zapewnienia większego bezpieczeństwa narodowego.

Iran jest jednym z najważniejszych państw, nie tylko w regionie Bliskiego Wschodu i od jego polityki zagranicznej zależeć będą w dużym stopniu bezpieczeństwo, nie tylko w tym regionie, lecz bezpieczeństwo międzynarodowe. Ponadto w odróżnieniu od takich mocarstw atomowych jak Indie, Pakistan i Izrael, nie wspominając o Korei Północnej, Iran jest sygnatariuszem Układu o nierozprzestrzenianiu broni jadrowej. Rzecz jednak w tym, że nie tylko władze USA obawiają się, że Iran może tej broni „użyczać” popieranemu przez siebie Hezbollahowi lub innym terrorystycznym organizacjom islamskim i dlatego domagają się znacznego ograniczenia irańskiego programu wzbogacania uranu i zaprzestania prac nad budową broni jądrowej.

Celem niniejszego artykułu jest analiza stanowisk obu stron i ocena szans na pełną normalizację stosunków polityczno-gospodarczych Iranu z USA i innymi państwami zachodnimi. Przyjęto następującą hipotezę, że obu stronom nie bardzo zależało do początku 2015 r. na kompleksowym rozwiązaniu wszystkich spornych problemów. Państwa zachodnie dążyły i nadal dążą do uniemożliwienia Iranowi budowy broni jądrowej, chociaż administracja Baracka Obamy pogodziła się chyba już z tym, że kraj ten 
prędzej czy później dołączy do grona mocarstw atomowych. Natomiast Iran, przedłużając negocjacje z pięcioma stałymi członkami Rady Bezpieczeństwa i Niemcami, stara się głównie o zniesienie wszystkich sankcji i o nawiązanie współpracy gospodarczej z krajami zachodnimi oraz o uznanie swojego suwerennego prawa do rozwoju programu atomowego i posiadania broni jądrowej. Broń ta traktowana jest nie tylko przez Iran, lecz przez wszystkie mocarstwa atomowe jako skuteczny „środek odstraszania” i gwarant bezpieczeństwa międzynarodowego.

\section{CZYNNIKI SPRZYJAJĄCE NORMALIZACJI}

Wybór w czerwcu 2013 r. umiarkowanego polityka irańskiego Hasana Rouhaniego na prezydenta Iranu niewątpliwie sprzyjał ,złagodzeniu” polityki zagranicznej i nastawienia tego kraju wobec państw zachodnich. Prezydent Hasan Rouhani w swoim przemówieniu na forum Zgromadzenia Ogólnego ONZ 24 czerwca 2013 r. dał wyraźnie sygnał, że Iran nie zamierza prowadzić wrogiej polityki wobec państw zachodnich i popierać różne ugrupowania terrorystyczne (Hamas w Strefie Gazy i Hezbollah w Syrii) oraz że będzie ściśle współpracować z Międzynarodową Agencją Energii Atomowej (IAEA). Jednocześnie uzależnił ewentualne ograniczenie irańskiego programu nuklearnego od zmniejszenia sankcji ekonomicznych, w tym szczególnie od „odmrożenia” irańskich aktywów dewizowych w bankach zachodnich i umożliwienia Iranowi eksportu ropy naftowej (Ereli, 2014: 15).

Sankcje gospodarcze zostały nałożone na Iran przez USA już w 1979 r. i w latach następnych (od 2007 roku) także przez inne państwa zachodnie. Nie doprowadziły one jednak do załamania się irańskiej gospodarki, ale okazały się skutecznym instrumentem nacisku prowadzącym do zmiany dotychczasowej polityki zagranicznej Iranu wobec Zachodu. Sankcje przyczyniły się między innymi do dużego spadku PKB (szczególnie w 2012 r. o prawie 5,8\% i 2\% w 2013 r. - zob. wykres 1), zwyżki cen większości towarów konsumpcyjnych, spadku dochodów z eksportu ropy naftowej i zwiększenia bezrobocia. Stany Zjednoczone stopniowo zwiększały liczbę różnych sankcji ekonomicznych począwszy od ataku w 1983 r. na koszary i ambasadę USA w Libanie i następnie w latach 90. XX wieku oraz po ataku z 11 września 2001 roku na World Trade Center (z którym Iran zresztą nie miał nic wspólnego), a skończywszy na 2012 r.

Te ostatnie sankcje zostały przy końcu listopada 2013 r., po zawarciu w Genewie tymczasowego porozumienia z Iranem, częściowo złagodzone, chociaż podstawowe zakazy zwiększenia eksportu irańskiej ropy naftowej ponad $1 \mathrm{mln}$ baryłek dziennie, czy też sprawa odmrożenia irańskich depozytów w zachodnich bankach, nadal pozostają w mocy (Bapat, Kwon, 2014: 69).

Należy zaznaczyć, że historyczne zaszłości dosyć długo utrudniały Stanom Zjednoczonym podjęcie negocjacji z Iranem w sprawie normalizacji wzajemnych stosunków. $\mathrm{Z}$ drugiej strony, władze Iranu starały się prowadzić w minionych trzech dekadach dosyć wyważona, opartą na realistycznej ocenie sytuacji geopolitycznej, politykę zagraniczną. Pomimo pełnej nienawiści retoryki w przemówieniach niektórych irańskich duchownych, przywódcy tego państwa zawsze uprawiali realpolitik $\mathrm{w}$ stosunku do wszystkich państw zachodnich, a także wobec takich mocarstw regionalnych jak ChRL 
Wykres 1. Zmiany tempa wzrostu PKB w latach 2004-2013 w \%

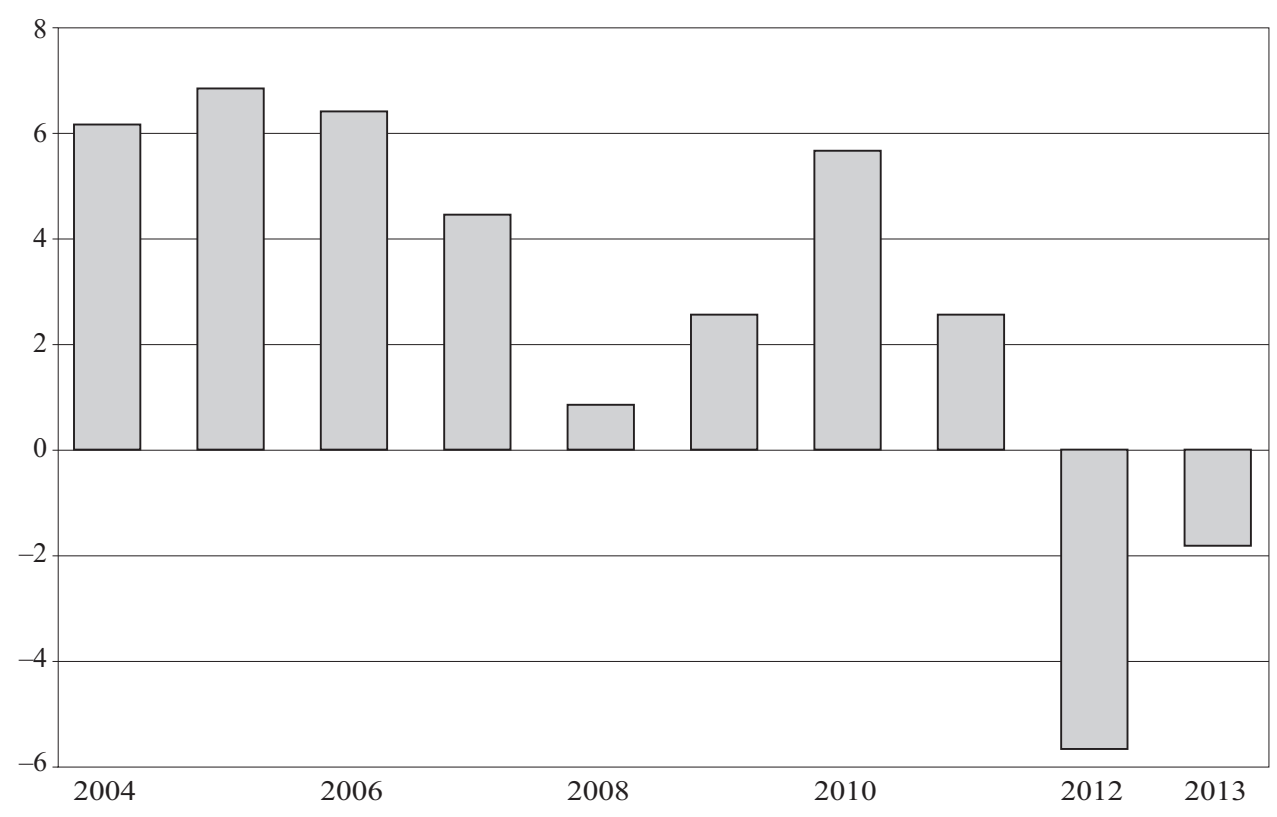

Źródło: Economist Intelligence Unit; EIA: Statistical Centre of Iran i Central Bank of Iran, 2013.

i Federacja Rosyjska. Dążenie władz w Teheranie do rozwoju energetyki nuklearnej i zbudowania broni jądrowej podyktowane było i jest interesem narodowym tego państwa. Posiadanie bowiem takiej broni mogłoby znacznie zwiększyć bezpieczeństwo Iranu w regionie Bliskiego Wschodu i zapewnić utrzymanie obecnego reżimu (rządów ajatollahów) w tym państwie. Władze w Teheranie zakładają, że Stany Zjednoczone ani też żadne inne państwo (np. Izrael) nie dokonają inwazji na Iran, jeśli to państwo będzie dysponować arsenałem nuklearnym (Rieffer-Flanagan, 2013: 169).

Ekipa prezydenta Hassana Rouhaniego stara się więc od połowy 2013 r. „pozycjonować" Iran na arenie międzynarodowej jako kraju nie wrogiego wobec USA i innych państw zachodnich oraz jako państwa, które sprzeciwia się użyciu broni atomowej i dalszemu jej rozprzestrzeniania. Jako przykład takiego, nowego podejścia podaje się często wypowiedzi najwyższego przywódcy Ali Chameneia, który w fatwie określił, broń jądrową mianem nieislamskiej. Jeśli jednak broń ta jest zabroniona przez islam, to można postawić pytanie, dlaczego Iran już za panowania szacha Rezy Pahlawiego zaczął rozwijać swój program nuklearny i od ponad 10 lat prowadzi prace nad wzbogacaniem uranu ponad 5\% poziom oraz w tajemnicy przed resztą świata kontynuuje prace nad skonstruowaniem głowic jądrowych? Państwa zachodnie nie posiadają niepodważalnych dowodów na to czy Iran już dysponuje takim potencjałem, który umożliwi mu budowę bomby atomowej. Od kilku lat starają się jednak nie dopuścić do tego, aby Iran, posiadający dobre kontakty z różnymi organizacjami terrorystycznymi na całym świecie, wszedł w posiadanie broni jądrowej. Powyższe dążenia wynikają z uzasadnionej obawy, że nikt poza samym Iranem, nie może powstrzymać go przed zbudowaniem własnej broni atomowej. Mocarstwom nuklearnym nie udało się w przeszłości po- 
wstrzymać Indie, Pakistan, Izrael i Koreę Północną przed zbudowaniem takiej broni, więc teraz to także może nie udać się z Iranem. Potwierdza to przebieg dotychczasowych negocjacji pięciu stałych członków Rady Bezpieczeństwa i Niemiec z Iranem, które rozpoczęły się 4 listopada 2013 r. w Genewie.

\section{PRZEDLUŻAJĄCE SIĘ NEGOCJACJE}

Od samego początku negocjacji w Genewie wielu zachodnich polityków podejrzewało Iran o to, że dąży on do zawarcia tylko tymczasowego, ,kompromisowego” porozumienia, aby zyskać na czasie. Sekretarz stanu John Kerry dosyć długo zdecydowanie sprzeciwiał się tego rodzaju planom zawarcia „tymczasowego porozumienia” stwierdzając, że: „Stany Zjednoczone nie pozwolą, aby zostało zawarte porozumienie [...], dzięki któremu Iran zyskiwałby na czasie, czy żebyśmy zaakceptowali porozumienie, które w zasadzie nie odpowiada na nasze podstawowe wątpliwości co do irańskiego programu nuklearnego". Należy dodać, że wcześniej, bo w połowie listopada $2013 \mathrm{r}$. J. Kerry podkreślił, że porozumienie w sprawie irańskiego programu nuklearnego może być „bardzo trudne”, ale możliwe. Zaznaczył przy tym, że większość sankcji nałożonych do tej pory na Iran pozostanie w mocy, nawet w przypadku osiagnięcia kompromisu ograniczającego program nuklearny prowadzony przez władze w Teheranie (Feith, 2013: 15). Także strona irańska nie zamierzała i jak się wydaje nie zamierza zrezygnować z realizacji programu nuklearnego. Ajatollah Ali Chamenei zaapelował do irańskich negocjatorów, by respektowali graniczne „czerwone linie” programu nuklearnego Iranu i „nie obawiali się gniewu wrogów”. Tymi granicami są m.in. kwestia wzbogacania uranu na terytorium Iranu oraz odmowa zamknięcia podziemnego ośrodka Fordo. A. A. Chamenei dodał też, że nawet nałożone na Iran sankcje gospodarcze nie zmuszą państwa do ustępstw w czasie negocjacji nuklearnych (Iran and its nuclear, 2013: 35). Można więc było założyć, że nie uda się osiagnąć kompromisowego porozumienia, które zaakceptują obie strony.

A jednak 24 listopada 2013 r. podpisano w Genewie tymczasowe porozumienie, które miało obowiązywać tylko przez pół roku. W porozumieniu tym Iran zobowiązał się do:

- zaprzestania wzbogacania uranu ponad 5\% (w energetyce jądrowej wystarczy 3,5\% stężenie, dla celów wojskowych używa się 90\%);

- „Zneutralizowania” posiadanych zapasów uranu wzbogaconego do blisko 20\% (taki poziom wedle dostępnej wiedzy udało się na razie osiagnąć irańskim atomistom);

- nieinstalowania nowych wirówek służących do wzbogacania uranu i nieuruchamiania części wirówek już zainstalowanych w zakładach w Natanz i Fordow;

- zatrzymania prac w reaktorze Arak, w którym można produkować pluton;

- wpuszczenia inspektorów Międzynarodowej Agencji Energii Atomowej do swoich instalacji nuklearnych, kopalni uranu i magazynów.

Natomiast strona zachodnia zobowiązała się do:

- uznania prawa Iranu do rozwoju energetyki nuklearnej;

- nienakładania nowych sankcji na Iran;

- zawieszenia sankcji w części zakazującej handlu metalami szlachetnymi;

- pozwolenia na licencyjne naprawy irańskich samolotów pasażerskich; oraz 
- odmrożenia 400 mln dolarów na stypendia zagraniczne dla irańskich studentów (Solomon, Norman, 2013: 13).

Genewskie tymczasowe porozumienie nie zniosło naftowego embarga i Iran w trakcie trwania tego porozumienia uzyskał możliwości eksportu tylko $1 \mathrm{mln}$ baryłek ropy dziennie. Dla porównania na początku 2012 r. państwo to eksportowało 2,5 $\mathrm{mln}$ baryłek ropy naftowej dziennie. Nie uchylono też sankcji nałożonych względem irańskich banków, nie została również odmrożona ogromna większość irańskich depozytów w wysokości 100 mld dolarów w zagranicznych bankach (Gwiazda, 2014b: 55). Porozumienie to otworzyło jednak dosyć wyboistą drogę, jak pokazały to późniejsze wydarzenia, do zawarcia trwałego porozumienia państw zachodnich z Iranem. Dopiero zawarcie takiego porozumienia stworzy podstawy do pełnej normalizacji stosunków politycznych i gospodarczych.

Początkowo wyznaczono sześciomiesięczny termin, w czasie którego obie strony zobowiązały się do wypracowania i uzgodnienia warunków trwałego porozumienia. Wielu ekspertów wyrażało wówczas, jak się okazało, słuszne obawy, że po tych sześciu miesiącach zostanie wyznaczony kolejny termin i negocjacje będą trwały w nieskończoność (Samore, 2013: 16). Wiele też przemawiało za tym, że przestawienie rozwoju programu atomowego na tory pokojowe zależeć będzie w większym stopniu od woli władz Iranu aniżeli od polityki USA i innych państw zachodnich wobec tego państwa. Strona zachodnia zgodziła się bowiem w podpisanym w Genewie tymczasowym porozumieniu, aby Iran zachował w całości, dotąd niezbyt rozpoznany przez ekspertów z IAEA, potencjał wzbogacania uranu. A potencjał ten szacowano w listopadzie $2013 \mathrm{r}$. na 9 ton uranu i około 18 tys. wirówek służących do jego wzbogacania oraz reaktor w miejscowości Arak wykorzystujący pluton (Iran's nuclear triumph, 2013: 16). Przy tak dużej liczbie wirówek Iran z łatwością może wzbogacić uran z poziomu $20 \%$ do $90 \%$, co umożliwia budowę bomby atomowej. Natomiast dla potrzeb rozwoju energetyki nuklearnej wystarczy wzbogacony uran do poziomu maksimum 5\%. Prawa do produkowania i wykorzystywania do celów pokojowych wzbogaconego uranu do 5\% zawartości izotopu $235 U$ nie negują państwa zachodnie, które jednak obawiają się, że Iran nie dotrzyma swoich zobowiązań lub zleci, w ramach outsourcingu, konstrukcję bomby atomowej Korei Północnej (Rosett, 2014: 13).

Należy podkreślić, że irańskiej broni nuklearnej najbardziej obawiają się Izrael i Arabia Saudyjska. To pierwsze państwo uważa, że Iran posiadający bomby atomowe mógłby spełnić groźby wypowiadane przez niektórych przedstawicieli najwyższych władz tego państwa i unicestwić Żydów. Natomiast przedstawiciele Arabii Saudyjskiej obawiają się utraty pozycji regionalnego mocarstwa na rzecz Iranu, który mógłby podporządkować sobie ten bogaty w ropę naftową region. Jednak Arabia Saudyjska, bez amerykańskiej pomocy nie jest w stanie samodzielnie przeciwstawić się Iranowi. Podobne ograniczenia w tym zakresie posiada Izrael, którego władze od 25 listopada 2013 r., tj. od podpisania tego tymczasowego porozumienia, zaczęły ostro krytykować porozumienie, podobnie jak , ugodową" politykę USA wobec Iranu. Władze w Tel-Avivie były i są zwolennikami opcji militarnej. Jednak nie są w stanie same bez pomocy USA wykonać skutecznego ataku na irańskie instalacje i ośrodki atomowe. Instalacje te są zresztą dobrze ukryte i zabezpieczone i dlatego nie są łatwym do zniszczenia celem (Kemp, Gay, 2014: 39). 
W trakcie toczących się negocjacji, które mają doprowadzić do zawarcia trwałego porozumienia, mało prawdopodobny jest wybór opcji militarnej. Takie propozycje wysuwane były zarówno przez władze Izraela, jak i przez niektórych polityków amerykańskich (Kroenig, 2012: 34). Zwolennicy opcji militarnej argumentowali, że prewencyjne uderzenie $w$ irańskie ośrodki nuklearne byłoby lepszym rozwiązaniem niż bierne oczekiwanie na to czy Iran ograniczy, zgodnie z żądaniami państw zachodnich, swój program atomowy czy też w ciagu najbliższych miesięcy przyspieszy jego realizację. Sporządzone przez różnych ekspertów analizy wskazujące, że „prewencyjna wojna” z Iranem byłaby obecnie mniej kosztowna i niebezpieczna aniżeli dopuszczenie do posiadania przez to państwo własnej broni atomowej oparte były jednak na dosyć „naciaganych” argumentach i niezbyt rzetelnej analizie kosztów i spodziewanych korzyści z „siłowego" rozwiązania omawianego problemu (The price of inaction, 2012: 4). $\mathrm{Z}$ tego powodu USA i inne państwa zachodnie chcą ten problem rozwiązać środkami dyplomatycznymi.

Sprzyja temu sytuacja geopolityczna, która w ostatnim czasie uległa dosyć znacznej zmianie. Zmieniła się w ostatnich paru latach także pozycja Iranu na Bliskim Wschodzie w wyniku nie tylko wydarzeń związanych z ,arabską wiosną”, lecz przede wszystkim w związku z przedłużającą się wojną domową w Syrii i powstaniem Państwa Islamskiego (dalej: ISIS) na części terytorium tego państwa i w Iraku. Władze Iranu nie są więc już najbardziej „nieprzewidywalnym aktorem” w tym regionie. Nie można więc zakładać, że po wyprodukowaniu broni nuklearnej chciałyby jej od razu użyć przeciwko Izraelowi czy też innemu państwu. Można i trzeba jednak pamiętać, że rozwijany przez Iran program jądrowy stanowi jeden z poważniejszych problemów dla bezpieczeństwa nie tylko w regionie Bliskiego Wschodu, lecz także dla bezpieczeństwa międzynarodowego. Takie państwa jak rywalizująca od dawna z Iranem o wpływy w tym regionie Arabia Saudyjska, a także Turcja i Egipt, z pewnością podjęłyby próby zbudowania własnej broni nuklearnej, co doprowadziłoby do wyścigu zbrojeń i jeszcze większego zaostrzenia sytuacji w tym regionie.

Zdają sobie z tego sprawę władze Stanów Zjednoczonych i ich sojusznicy, którzy dążą do dyplomatycznego, a nie siłowego rozwiązania tej kwestii i rezygnacji przez Iran z dążenia do budowy broni atomowej. Tym też można tłumaczyć „wyrozumiałość" negocjatorów zachodnich w tym szczególnie cierpliwość i ugodowość administracji Baracka Obamy, którzy już po raz trzeci zgodzili się na przedłużenie negocjacji do końca czerwca 2015 r. Należy przypomnieć, że dyplomacji Iranu udało się najpierw wynegocjować termin zawarcia trwałego porozumienia na lipiec, a następnie na listopad 2014 r. i po raz trzeci na czerwiec 2015 r. Niektórzy eksperci podejrzewają jednak, że Iran potrzebuje jeszcze siedem miesięcy do wyprodukowania bomby atomowej (Norman, 2014: 8). Władze tego państwa wykorzystują więc fakt, że nastąpiło znaczne pogorszenie stosunków politycznych między Rosją i Stanami Zjednoczonymi. Ponadto w USA doszło do silnych podziałów politycznych, a bardziej podzielona niż zintegrowana Unia Europejska znajduje się w fazie stagnacji gospodarczej i nie wykazuje większego zainteresowania szybką normalizacją stosunków politycznych z Iranem. Przedłużenie negocjacji z Iranem do czerwca 2015 r. wynika także w dużym stopniu z realizacji przez prezydenta Baracka Obamę strategii dyplomatycznego załatwiania tych wszystkich spornych kwestii, które, jego zdaniem, można roz- 
wiązać bez użycia siły militarnej. Pewien wpływ na tego rodzaju ugodową politykę USA wobec Iranu wywiera także nowa sytuacja geopolityczna na Bliskim Wschodzie i walka ze wspólnym wrogiem, jakim jest Państwo Islamskie.

\section{WSPÓLPRACA USA Z IRANEM W WALCE Z PAŃSTWEM ISLAMSKIM}

Powstanie i ekspansja militarna Państwa Islamskiego przyczyniła się do zmiany pozycji Iranu w regionie Bliskiego Wschodu. Przywódcy tego państwa zawsze dążyli do podporządkowania sobie swoich sąsiadów i stworzenia czegoś w rodzaju ,aliansu pan-Islamskiego", oczywiście pod przewodnictwem Islamskiej Republiki Iranu. Dążenia te $\mathrm{z}$ wielu różnych względów nie miały szans na powodzenie. Szyicki Iran bowiem stale rywalizował i nadal współzawodniczy z popierającą sunnitów i różne ugrupowania salafickie - proamerykańską Arabią Saudyjską. Rywalizacja ta zresztą nie ogranicza się tylko do religijnego wymiaru. Iran bowiem popierał tam, gdzie to dawało mu korzyści także sunnickich islamistów w Tunezji i Egipcie oraz zbliżył się do Bractwa Muzułmańskiego, podczas gdy Arabia Saudyjska potępiała tę organizację i poparła zamach stanu z 3 lipca 2013 r. przeciwko prezydentowi Muhammadowi Mursiemu. Iran był także i jest nadal sojusznikiem reżimu z Damaszku, którego hasła są bardzo dalekie od zasad islamskiej rewolucji. Partnerstwo to wynika jednak bardziej z interesów geopolitycznych niż z religijnych (Mohtadi, 2013: 20). Z kolei władze Arabii Saudyjskiej do niedawna hojnie wspierały finansowo różne grupy dżihadystów walczących w Syrii przeciwko oddziałom rządowym, a także przeciwko niektórym oddziałom rebelianckim. Należy zaznaczyć, że także władze Federacji Rosyjskiej popieraja, podobnie jak Iran, reżim Bassara al-Assada w Syrii. Do niedawna więc władze w Iranie skłonne były się liczyć bardziej ze zdaniem Rosji w sprawie Syrii i Iraku, aniżeli ze zdaniem USA.

Sytuacja ta uległa jednak diametralnej zmianie latem 2014 r., kiedy działające na części terytorium Syrii Państwo Islamskie zaatakowało Irak i bardzo szybko opanowało północno-zachodnią część tego państwa. Powstanie i militarna ekspansja ISIS były możliwe dzięki rozpadowi struktur państwowych w Syrii w ostatnich paru latach oraz dzięki poparciu niektórych plemion w Iraku. Państwo Islamskie jest dosyć specyficzną i trudną do pokonania organizacja, którą tworzą nie tylko dżihadyści. Nie posiada łatwych do zlokalizowania baz wojskowych, dlatego efekty rozpoczętych przez USA i inne państwa sojusznicze ataków powietrznych skierowanych przeciwko tej organizacji terrorystycznej nie są imponujące. Dotychczasowe bombardowania nie doprowadziły do jej rozbicia. Administracja Baracka Obamy coraz bardziej skłania się do wysłania do Iraku kilku tysięcy żołnierzy amerykańskich i oddziałów wojskowych koalicji kilkudziesięciu państw, które zobowiązały się do współpracy w walce z dżihadystami (Thompson, 2015: 66). Państwo Islamskie jest bowiem dobrze uzbrojone i dzięki przejętym szybom naftowym i rafineriom posiada także spore środki finansowe. Według niektórych szacunków ISIS z produkcji i przemytu ropy naftowej uzyskiwało przy końcu 2014 r. około 2 mln dolarów dziennie (Dagher, 2014: 10-11). Na początku sierpnia 2014 r. Państwo Islamskie kontrolowało siedem pól naftowych i rafinerii w Iraku oraz sześć pól naftowych we wschodniej Syrii. ISIS mogło wykorzystywać jedynie połowę potencjału produkcyjnego, które kontrolowało, ale - dzięki wykorzysta- 
niu sprawnej, regionalnej sieci przemytników - nie miało żadnego problemu ze sprzedażą tego, co udawało się wypompować. Prowadzone przez USA i jej sojuszników od września 2014 r. bombardowania wymierzone są także w szyby naftowe, rafinerie i konwoje przewożące cysternami ropę do granicy z Turcją. Bombardowania te zniszczyły dziesiątki tych szybów i cystern, co pozbawiło dżihadystów kierujących Państwem Islamskim znacznej części dochodów przeznaczonych na ich ekspansję militarną w Syrii i Iraku.

Jednocześnie doszło do rozszerzenia koalicji państw walczących z ISIS, także o Iran i inne kraje Zatoki Perskiej. Już we wrześniu ubiegłego roku Iran podjął z USA współpracę w celu zwalczenia sannickich bojowników w Iraku, którzy prześladują szyitów i mniejszości religijne w tym kraju. Wprawdzie Iran popierający reżim prezydenta Assada oraz pozostałe kraje Zatoki Perskiej mają inne cele odnośnie przyszłości Syrii i Iraku niż USA i państwa zachodnie, ale mają też wspólnego wroga, jakim jest ISIS i sunniccy radykałowie w Iraku (Males, 2014: 9). Z kolei USA i państwa zachodnie mają dosyć ograniczone możliwości zaangażowania większych sił i środków w walkę z ISIS. Zarówno opinia publiczna w USA, jak i w Europie sprzeciwia się wysłaniu do Syrii i Iraku wojsk lądowych, które mogłyby pokonać dżihadystów. Same bombardowania zapewne nie doprowadzą do realizacji tego celu. Jednak politycy zachodni muszą się liczyć z opinią swoich wyborców, którzy doskonale znają bilans dotychczasowej, bardzo kosztownych interwencji wojsk USA i jej sojuszników w Iraku i Afganistanie. Dlatego m.in. walka z Państwem Islamskim stała się dla USA pretekstem do sojuszu z Turcją i podjęcia współpracy wojskowej z Iranem, aby przy pomocy tych państw ograniczyć rozwój i ekspansję ISIS najpierw w Iraku, a następnie także w Syrii.

Tym też można tłumaczyć dosyć ugodową politykę administracji prezydenta Baracka Obamy w negocjacjach z Iranem w sprawie ograniczenia przez to państwo programu nuklearnego. Wynik tych negocjacji jest ciagle niepewny, podobnie zresztą nie bardzo wiadomo, jak długo utrzyma się faktyczny sojusz USA z Iranem zawarty z konieczności wobec narastającego zagrożenia ze strony Państwa Islamskiego i sunnickich radykałów w Iraku (Solomon, Abi-Habib, 2014: 3). Na początku grudnia 2014 r. siły Iranu dokonały ataków lotniczych na cele ISIS w Iraku w prowincji Divala. Była to swoista demonstracja siły i chęci większego zaangażowania się w walkę z tą organizacją. Należy zaznaczyć, że w regionie tym tylko Turcja i Iran posiadają odpowiednie samoloty wojskowe (F-4 Phantom II), które mogą prowadzić operacje bojowe na tak rozległym terytorium. Jednak władze Turcji nie podejmują - jak dotychczas - tego rodzaju ataków na dżihadystów ani z powietrza, ani z lądu. Przykładem mogło być nieudzielenie przez Turcję pomocy Kurdom walczącym z bojownikami ISIS w mieście Kobane. Ci pierwsi od dawna domagają się utworzenia z części terytorium Turcji i Iraku własnego państwa. Stąd władzom Turcji nie bardzo zależy na pomaganiu Kurdom, do czego zachęcaja je Stany Zjednoczone. Z kolei Iran bardziej z konieczności niż $\mathrm{z}$,wolnego wyboru” stara się współpracować ze wszystkimi mocarstwami w regionie Bliskiego Wschodu w celu utrzymania status quo w tej części świata. Taka polityka podyktowana jest także dążeniem do utrzymania swojej dominującej pozycji w regionie, w którym Iran został „otoczony” przez wrogie wobec niego „siły salafickie”. Należy podkreślić, że siły te i wszyscy sunnici uważają szyizm, czyli odłam islamu będący 
religią państwową w Iranie, za herezję. Podziały między szyitami i sunnitami uległy w ostatnich latach pogłębieniu. Dlatego irańscy ajatollahowie porzucili już swoje marzenia o przewodzeniu całemu światu muzułmańskiemu w walce z Zachodem. Dążą raczej do tego, aby Iran odzyskał swoją pozycję na arenie międzynarodowej poprzez normalizację stosunków polityczno-gospodarczych z USA i innymi państwami zachodnimi i umocnił swoją pozycję w regionie Bliskiego Wschodu.

\section{PERSPEKTYWY ZAWARCIA TRWALEGO POROZUMIENIA}

Dotychczasowe negocjacje nie przyniosły spodziewanych przez obie strony efektów. Negocjacje te zostały przy końcu listopada 2014 r. po raz trzeci przedłużone do końca czerwca 2015 r. Do końca marca 2015 r. zaplanowano uzgodnienie „ramowego” porozumienia, które ma stanowić podstawę trwałych uzgodnień 30 czerwca $2015 \mathrm{r}$. Negocjacje dotyczące ramowego porozumienia prowadzone były w Lozannie i ostatecznie udało się podpisać porozumienie ramowe 2 kwietnia $2015 \mathrm{r}$. Sam fakt kontynuacji rozmów państw zachodnich z Iranem należy uznać za sukces. Natomiast brak konkretnych ustaleń w zawartym w Lozannie ramowym porozumieniu można uznać za niepowodzenie. Faktem bowiem jest, że udało się tylko uzgodnić dosyć ogólny zarys ramowego porozumienia, które ma stanowić podstawę do dalszych negocjacji w celu „dopracowania i zredagowania trwałego porozumienia” państw zachodnich z Iranem (Repetowicz, 2015: 1). Władze Iranu zgodziły się na prowadzenie wzbogacania uranu tylko w ośrodku w Natanz, natomiast ośrodek Fordow ma zostać przekształcony w centrum badawcze na co najmniej 15 lat i nie będzie tam materiału rozszczepialnego. Zgodził się także na ograniczenie liczby wirówek z obecnych 19000 do 6104 sztuk, przy czym tylko ok. 5 tys, tych wirówek będzie mogło wzbogacać uran przez najbliższe 10 lat do poziomu poniżej 3,67\% (ibidem). Jednocześnie Iran zobowiązał się do zmniejszenia swoich zapasów nisko wzbogaconego uranu z $10000 \mathrm{~kg}$ do $300 \mathrm{~kg}$ oraz do nieotwierania nowych ośrodków wzbogacania uranu.

W zamian za ograniczenie swojego programu nuklearnego zostaną stopniowo zniesione amerykańskie i europejskiej sankcje nałożone na Iran, ale dopiero wtedy, kiedy inspektorzy z MAEA stwierdza, że Iran wypełnia wynikające z zawartego porozumienia zobowiązania. Sankcje te mogą więc być w każdej chwili ponownie nałożone, jeśli Iran nie umożliwi skutecznej kontroli swoich ośrodków wzbogacania uranu. Można założyć, że nie do wszystkich tych ośrodków zostaną wpuszczeni „kontrolerzy” z MAEA. W omawianym ramowym porozumieniu nie wyszczególniono bowiem wszystkich tych ośrodków ani też nie ustalono precyzyjnie tempa wprowadzania w życie przez Iran uzgodnionych ograniczeń. Nie podano także, kiedy zostaną zniesione wszystkie zachodnie sankcje gospodarcze. Krytyka tego ramowego porozumienia koncentruje się przede wszystkim na zapisach dotyczących nieskutecznych mechanizmów kontrolnych, które mogą umożliwić Iranowi kontynuację, tak jak dotychczas, swojego programu nuklearnego i jednoczesnego, po zniesieniu sankcji, korzystania z rozwoju współpracy gospodarczej z państwami zachodnimi.

Najbardziej mogą na tym skorzystać kraje europejskie i ChRL, które z pewnością będą starały się jak najszybciej znormalizować swoje relacje gospodarcze z Iranem, 
aby wyprzedzić amerykańską konkurencję. Są także takie kraje, które będą starały się storpedować zarówno najnowsze, ramowe porozumienie z Lozanny, jak również planowane na koniec czerwca br. trwałe porozumienie z Iranem. Należy do nich z pewnością Izrael, którego władze konsekwentnie utrzymują, że kontrola implementacji tego porozumienia $z$ Iranem jest w praktyce niemożliwa. Także Arabia Saudyjska, która na parę dni przed terminem zakończenia negocjacji z Lozannie podjęła antyszyicką interwencję zbrojną w Jemenie, ma swoje powody, aby utrudnić zawarcie trwałego porozumienia państwom zachodnich z Iranem. Także Rosja, która deklaruje przynajmniej, że jest ,głównym" sojusznikiem Iranu, nie jest raczej zainteresowana zawarciem trwałego porozumienia z tym państwem. Może ono spowodować dalszy spadek cen ropy naftowej, a normalizacja stosunków gospodarczych Europy z Iranem oznaczałaby także otwarcie nowych możliwości tranzytowych ropy naftowej i gazu nie tylko z Iranu, lecz także z Iraku i krajów basenu Morza Kaspijskiego. Wydaje się więc, że Rosja ma także swoje powodu do torpedowania tego porozumienia poprzez usztywnienie stanowiska Iran. A to ostatnie będzie starała się zapewnić poprzez „podsuwanie iluzji możliwego partnerstwa i korzyści gospodarczych związanych ze wspólnymi projektami” czy też dostawami do Iranu rosyjskiego sprzętu wojskowego (Dżemal, 2015: 6).

Zarówno władze Iranu, jak uczestniczący w negocjacjach przedstawiciele państw zachodnich oraz Rosji i ChRL zdają sobie sprawę, że gra toczy się o bardzo wysoką stawkę. Przedłużanie tych negocjacji, czyli swoista gra na czas i unikanie podpisania trwałego porozumienia bardziej, jak się wydaje, szkodzi interesom Iranu niż interesom USA i pozostałych państw zachodnich. Najbardziej zainteresowanym państwem w osiagnięciu trwałego porozumienia $\mathrm{z}$ Iranem w sprawie ograniczenia rozwoju programu atomowego jest Izrael. Władze tego państwa zakładaja, że Stany Zjednoczone w końcu skłonią Iran do podpisania trwałego porozumienia, aby uniknąć konieczności interwencji zbrojnej. Ograniczeniem przez Iran programu nuklearnego i rezygnacji przez to państwo z posiadania broni atomowej zainteresowanych jest więcej państw. Państwa te jednak wolałyby, aby ten problem rozwiązały Stany Zjednoczone. Także przez zniszczenie irańskich instalacji jądrowych, jeśli w połowie $2015 \mathrm{r}$. nie dojdzie do zawarcia z Iranem trwałego porozumienia.

To ostatnie rozwiązanie wydaje się mało prawdopodobne za kadencji prezydenta Baracka Obamy, który dąży do kompromisowego rozwiązania problemu irańskiego bez użycia siły militarnej. Wiele wskazuje na to, że B. Obama chciałby zostawić rozwiązanie „problemu irańskiego" swojemu następcy. Jednak kolejna administracja USA, niezależnie od tego czy prezydentem zostanie kandydat republikanów, czy demokratów, będzie zapewne mniej skłonna do ulegania żądaniom władz Iranu i poszukiwania kompromisowych rozwiązań korzystnych głównie dla tego państwa. Jak stwierdziła na początku września $2014 \mathrm{r}$. Hillary Clinton, która ma duże szanse na wygranie wyborów prezydenckich w USA, nie istnieje coś takiego jak ,,prawo do wzbogacania uranu” (The Atlantic, 2014: 1). Prawo międzynarodowe jedynie nie zakazuje tego wzbogacania, ale musi być ono prowadzone pod kontrolą inspektorów ONZ i Międzynarodowej Agencji Energii Atomowej (IAEA). A Iran nie dopuszcza inspektorów tej agencji do wielu swoich ośrodków jądrowych ani też nie przedstawia pełnych danych odnośnie ilości posiadanego i ciagle wzbogacanego uranu (Teheran failing, 2014: 28). Stany Zjednoczone i inne państwa zachodnie zajęte obecnie bardziej walką z Państwem Islamskim, tolerują 
tego rodzaju zachowanie władz w Teheranie i brak konkretnych zobowiązań tego państwa odnoście ograniczenia programu nuklearnego. Iran potrzebny jest im jako sojusznik w walce w ISIS. Tym też można tłumaczyć przedłużające się negocjacje, które wcale nie muszą zakończyć się 30 czerwca 2015 r.

Od sytuacji geopolitycznej nie tylko w regionie Bliskiego Wschodu zależeć będzie w dużym stopniu to czy i kiedy Iran zgodzi się na przyjęcie zachodnich propozycji dotyczących ograniczenia programu jądrowego. Jeśli nie zgodzi się na realizację uzgodnionych 2 kwietnia br. w Lozannie ustaleń, to zapewne zwiększy się presja Izraela (i Arabii Saudyjskiej) na USA, aby zbombardować irańskie instalacje atomowe. Jednak najbardziej prawdopodobną reakcją administracji Baracka Obamy będzie, w przypadku fiaska negocjacji i braku zwarcia $z$ Iranem trwałego porozumienia, nie tyle atak lotniczy na te instalacje, ile nałożenie na ten kraj sankcji ekonomicznych. Natomiast inne mocarstwa atomowe, biorące udział w negocjacjach z Iranem, takie jak ChRL i Rosja raczej nie będą ograniczać swojej współpracy gospodarczej w Iranem. Co więcej, Rosja prowadzi od pewnego czasu rozmowy z władzami Iranu dotyczące zwiększenia w 2015 r. wymiany handlowej o 20 mld dol. Także ChRL zamierzają zwiększyć handel z Iranem, początkowo w oparciu o wymianę barterową (irańska ropa za chińskie towary przemysłowe). Podobnie przygotowują się do handlu z Iranem kraje europejskie, które nawet w przypadku fiaska negocjacji z Iranem zamierzają rozwijać z tym krajem współpracę gospodarczą.

Różne interesy gospodarcze poszczególnych państw biorących udział w negocjacjach z Iranem w sprawie normalizacji stosunków polityczno-gospodarczych mogą zagrozić wspólnemu dążeniu tych państw do powstrzymania Iranu przed uzyskanie dostępu do broni atomowej. Dopóki jednak toczą się negocjacje w tej sprawie, dopóty jest nadzieja, że uda się w końcu podpisać z Iranem trwałe porozumienie i doprowadzić do pełnej normalizacji stosunków polityczno-gospodarczych z tym państwem. Szanse na taką normalizację nieco wzrosły po zawarciu ramowego porozumienia w Lozannie. Jednak obu stronom nie udało się rozwiązać w trakcie dotychczasowych negocjacji w sposób kompleksowy wszystkich spornych problemów i trudno jest liczyć na to, że uda się to zrobić w ciągu najbliższych paru miesięcy.

\section{Bibliografia}

Bapart N. A., Kwon B. R. (2014), When are sanctions effective?, „International Organization”, No. 4. Bipartisan Policy Center Report (2012), Washington D.C.

Boot M. (2014), The war od ISIS: more than one battle, „The Wall Street Journal”, 24-26.10.2014.

Czornik K. (2012), Wschód w polityce zagranicznej Stanów Zjednoczonych w latach 1945-2012, Katowice.

Dagher S. (2014), Oil fuels the war between Kurds and Islamic State, „The Wall Street Journal”, 25.11.2014.

Dżemal G. (2015), Partnerstwo Rosji i Iranu. Jakie partnerstwo?, http://geopolityka.org (3.03.2015).

Enayat H. (2013), Law, state, and society in modern Iran, New York.

Ereli A. (2014), A year of Iranian „moderation”, „The Wall Street Journal”, 26-28.09.2014. 
Faucon B., Spendle B. (2014), Iran's economy staggers as oil falls, deal stalls, , The Wall Street Journal", 24-28.12.2014.

Feith D. J. (2013), Sanctions on Iran won 't be cranked back up, „The Wall Street Journal”, 19.11.2013.

Fiedler R. (2013), Od sankcji do sankcji. Polityka Stanów Zjednoczonych wobec Islamskiej Republiki Iranu, „Przegląd Strategiczny”, nr 1.

Frear T. (2015), The Russian-Iranian military agreement: another perspective, „The Diplomat”, 16.02.2015.

Ganij A. (2013), Who is Ali Khamenei, „Foreign Affairs”, No. 5.

Gwiazda A. (2014), Perska zagrywka, http://www.wsensie.pl (4.12.2014).

Gwiazda A. (2014b), Odwilż w stosunkach politycznych Iranu z Zachodem?, Kwartalnik „Bellona”, nr 2.

Hildreth S. A. (2012), Iran's ballistic missile and space launch programs, Congressional Research Service, Washington D.C, 6.12.2012.

Iran and its nuclear plans (2013), „The Economist”, No. 42.

Jain A. (2011), Nuclear weapons and Iran's global ambitions: troubling scenarios, Washington D.C.

Kam E. (2007), The Iranian nuclear threat and the Israeli options, „Contemporary Security Policy”, No. 3.

Kapiszewski J. (2013), Izrael krytykuje porozumienie z Iranem, „Dziennik Gazeta Prawna”, 25.22.2013.

Kaźmierska A. (2013), Tymczasowa umowa jądrowa, „Rzeczpospolita”, 25.11.2013.

Kemp G., Gay A. J. (2014), War with Iran, New York.

Kroenig M. (2012), Time to attack Iran, „Foreign Affairs”, No. 1.

Lider Hezbollahu pozytywnie ocenia porozumienie nuklearne (2015), http://wsensie.pl (7.04.2015).

Lindsay J. M., Takeyh R. (2010), After Iran gets the bomb, „Foreign Affairs”, No. 2.

Majd H. (2009), Ajatollah śmie watpić. Paradoks wspótczesnego Iranu, Kraków.

Majd H. (2011), Demokracja ajatollahów. Wyzwanie dla Iranu, Kraków.

Malas N. (2014), U.S. Iran on same side in aiding Kurds, ,The Wall Street Journal”, 15-17.08.2014.

Mitnick J. (2013), Israel bashes pact with Teheran, „The Wall Street Journal”, 25.11.2013.

Mohtadi A. (2013), Stosunki irańsko-syryjskie po zmianach w Teheranie, „Le Monde Diplomatique - Polska”, nr 10.

Norman L. (2014), Big gaps with Iran on nuclear deal remain, „The Wall Street Journal”, 14.07.2014.

Pillar P. R. (2013), The role of Villain: Iran and U.S. foreign policy, „Political Science Quarterly”, No. 2.

Pollack K. (2013), Unthinkable: Iran, the bomb and American strategy, New York.

Rago J. (2014), Inside the war against Islamic State, „The Wall Street Journal”, 29.12.2014.

Rajca M. (2013), Szpiedzy Iranu, „Uważam Rze”, nr 43-44.

Repetowicz W. (2015), Sukces czy fiasko negocjacji mocarstw z Iranem?, http://www.defence24.pl (3.04.2015).

Rieffer-Flanagan B. A. (2013), Evolving Iran: an introduction to politics and problems in the Islamic Republic, Washington D.C.

Rosett C. (2013), An Iran-North Korea nuclear partnership?, „The Wall Street Journal”, 13.06.2013.

Rosja oferuje Iranowi nowoczesny system S-300VM (2015), http://defence24.pl (24.02.2015).

Rosja i Iran rozszerzaja wspótprace wojskowa (2015), http://defence24.pl (20.01.2015).

Siemiątkowski J. (2013), Iran jako mocarstwo regionalne. Polityka zagraniczna Islamskiej Republiki Iranu wczoraj $i$ dziś, „Polityka Narodowa”, nr 13.

Solomon J. (2014), Abi-Habib M., U.S. Iran relations move to detente, „The Wall Street Journal”, 30.10 .2014 . 
Solomon J., Norman L. (2013), Iran and six World powers in nuclear deal, „The Wall Street Journal”, 25.11.2013.

Special Report Iran: The revolution is over (2014), „The Economist”, No. 44.

Stephens B. (2014), Iran cheats, Obama whitewashes, „The Wall Street Journal”, 26.11.2014.

Stephens B. (2014), Iran doesn't want a deal, „The Wall Street Journal”, 14.05.2014.

Teheran failing to release atomic energy data (2014), „The Independent”, 8.11.2014.

Thompson M. (2015), The general's burden, „Time”, 5.01.2015,

Usborne D. (2014), How to dismantle a nuclear programme: Iran and West make progress on deal, "The Independent", 23.04.2014.

Wspótczesne oblicza Iranu (2012), (red.) M.Chrościcki, Kraków.

\title{
STRESZCZENIE
}

Celem artykułu jest analiza dotychczasowych osiągnięć negocjacji prowadzonych przez pięciu stałych członków Rady Bezpieczeństwa ONZ i Niemiec z władzami Iranu. Negocjacje skierowane są na ograniczenie irańskiego programu nuklearnego i normalizację wzajemnych stosunków. Porozumienie tymczasowe, podpisane w listopadzie 2013 r. w Genewie nie doprowadziło do zawarcia ostatecznych uzgodnień. Wynegocjowane 2 kwietnia 2015 r. porozumienie ramowe z Lozanny, choć powinno być uznane za sukces przez fakt prowadzenia rozmów, to brak konkretnych ustaleń nakazuje uznać je za negocjacyjne niepowodzenie.

\section{UNCERTAIN NORMALIZATION OF POLITICAL AND ECONOMIC RELATIONS OF IRAN WITH THE WEST}

\begin{abstract}
This article analyses and assesses the hitherto achievements in the negotiations of the five permanent members of the Security Council plus Germany with Iran devoted to the limitation of its nuclear program and normalization of the mutual relations. This is prerequisite of the full normalization of political and economic relations between Iran and Western states. An interim agreement struck in the end of November 2013 in Geneva has not led, for the time being, to the signing of the permanent agreement. On the contrary, the negotiations were extended for the third time since November 2013 till June 2015. There is a danger that Iran will get another extension in June this year and will be able to play for time again. Thus it is reasonable to doubt whether Iran wants a deal with the West or tries to produce a nuclear bomb in the near future, The Obama administration conducts rather ,soft” policy towards Iran as the U.S. needs that country in the war with the Islamic State. On the other hand even the present U.S. administration cannot accept a deal that allows Iran to expand its nuclear programme and enrich uranium to $20 \%$. From various reasons the present stalemate in the negotiations with Iran cannot be resolved with the use of military force. Thus the only hope is that Iran will reconsider all benefits connected with the normalization of its economic and political relations with the West and finally sign a deal with the United States and other Western states.
\end{abstract}


